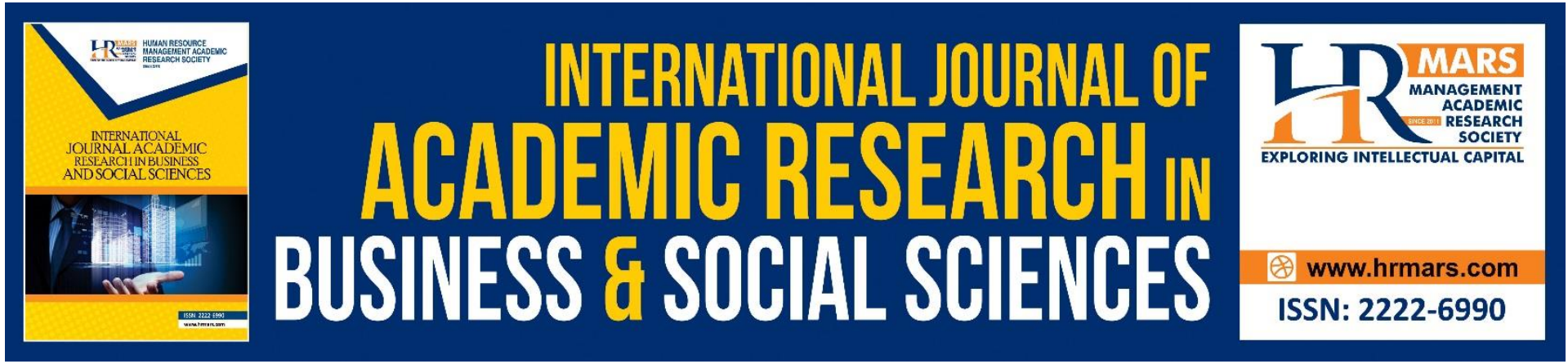

\title{
Perceived Stress Among UiTM Students During Open and Distance Learning (ODL)
}

Nor Mariyah Abdul Ghafar, Nur Faezah Jamal \& Nurhasniza Idham Abu Hasan

To Link this Article: http://dx.doi.org/10.6007/IJARBSS/v11-i8/10893

DOI:10.6007/IJARBSS/v11-i8/10893

Received: 21 June 2021, Revised: 24 July 2021, Accepted: 14 August 2021

Published Online: 30 August 2021

In-Text Citation: (Ghafar et al., 2021)

To Cite this Article: Ghafar, N. M. A., Jamal, N. F., \& Hasan, N. I. A. (2021). Perceived Stress Among UiTM Students During Open and Distance Learning (ODL). International Journal of Academic Research in Business and Social Sciences, 11(8), 1780-1792.

Copyright: @ 2021 The Author(s)

Published by Human Resource Management Academic Research Society (www.hrmars.com)

This article is published under the Creative Commons Attribution (CC BY 4.0) license. Anyone may reproduce, distribute, translate and create derivative works of this article (for both commercial and non-commercial purposes), subject to full attribution to the original publication and authors. The full terms of this license may be seen at: http://creativecommons.org/licences/by/4.0/legalcode

Vol. 11, No. 8, 2021, Pg. 1780 - 1792

Full Terms \& Conditions of access and use can be found at http://hrmars.com/index.php/pages/detail/publication-ethics 


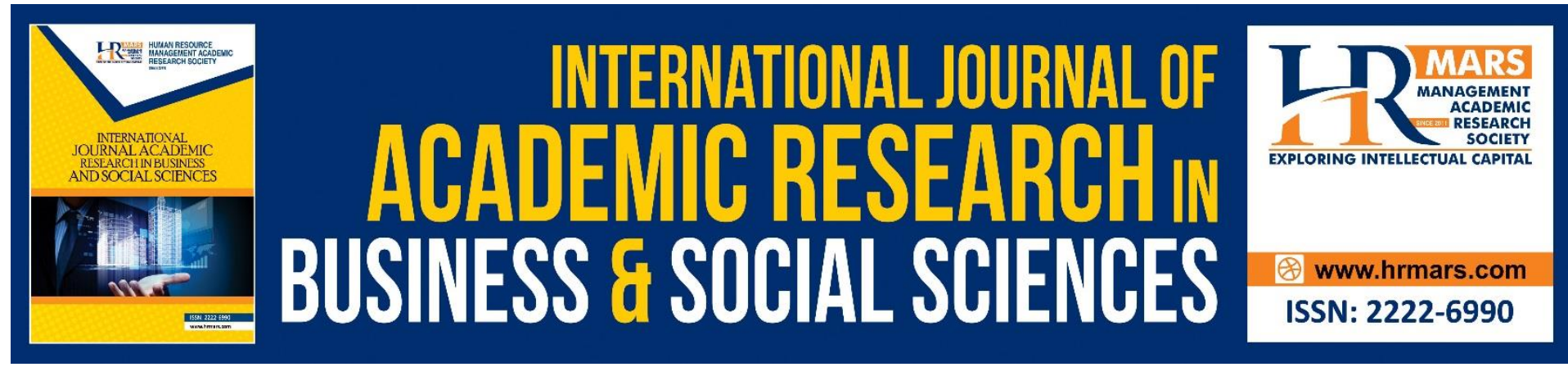

\title{
Perceived Stress Among UiTM Students During Open and Distance Learning (ODL)
}

\author{
Nor Mariyah Abdul Ghafar, Nur Faezah Jamal \& Nurhasniza \\ Idham Abu Hasan
}

Faculty of Computer \& Mathematical Sciences

Universiti Teknologi MARA (UiTM), Perak Branch, Tapah Campus, Malaysia.

\begin{abstract}
The higher education system is one of the sectors that has been affected by the coronavirus disease 2019 (COVID-19) pandemic. In response to that, Universiti Teknologi MARA (UiTM) has moved all classes to open and distance learning (ODL) effective 13 April 2020. ODL has greatly assisted the process of teaching and learning during the pandemic, but the sudden adoption from face-to-face learning to ODL can lead to stress among university students. Thus, this study aimed to identify the level of stress perceived by UiTM students during ODL and explore the influence of socio-demographic characteristics on the level of perceived stress among UiTM students during ODL. A cross-sectional survey design was used which was constructed of three main parts; demographic characteristics, Perceived Stress Scale-10 (PSS10) developed by Cohen, Kamarck, and Mermelstein (1983), and a qualitative exploratory question. The finding concluded that in general, UiTM students showed moderate stress during ODL. The factors that contributed to this are a poor internet connection, academic workload, high academic workload, deadline of assignment, internet connection, learning environment, and family problems.
\end{abstract}

Keywords: COVID-19, Open and Distance Learning, PSS, Stress, Students

\section{Introduction}

The emergence of the coronavirus disease 2019 (COVID-19) pandemic has changed how we live our daily lives. From social distancing to staying at home, all people in different age groups are affected and have to learn to live in a new norm. Malaysia is one of the countries that have exercised Movement Control Order (MCO) starting 18 March 2020 through the announcement made by the Prime Minister of Malaysia. In response to the announcement, many sectors have to be closed down to minimize the risk of spreading COVID-19.

The higher education system is one of the sectors that has been affected by the pandemic. Universities need to be closed down and changes need to be implemented to make sure that teaching and learning can still be delivered. This has marked a nationwide open and distance learning $(\mathrm{ODL})$ to replace face-to-face classroom teaching and learning during the pandemic. 
In response to that, Universiti Teknologi MARA (UiTM) has moved all classes to ODL effective 13 April 2020. ODL offers greater openness and flexibility where teaching is conducted by someone who is geographically separated (Cant, Wiid, \& Machado, 2013) and away from the learner (Ghosh et al., 2012). It can be conducted by utilizing electronic devices such as laptops and mobile phones through online platforms such as Google classroom, Massive Open and Online Course (MOOC), and UFuture.

Even though ODL greatly assists the process of teaching and learning during the pandemic, the short period to adapt from face-to-face learning to ODL among students can lead to stress and panic (Mheidly, Fares, \& Fares, 2020). Stress can then trigger depression which can be complicated by anxiety (Visnjic et al., 2018). Although UiTM has been integrating face-to-face learning with online learning through blended learning in certain courses for the past few years, most students are not ready for the sudden adoption of ODL since it depends exclusively on online learning. The problem in assessing internet connection will make them less motivated and reduce confidence (Almaiah, Al-Khasawneh, \& Althunibat, 2020). The increased exposure to smart devices and screens has also been reported to increase personal stress and burnout level (Sansone \& Sansone, 2013). Khouja et al. (2019) also found that there is a positive association between the increase of computer usage among teenagers with both anxiety and depression.

In addition, previous studies have shown that individual mental health can be negatively influenced by disease outbreaks. According to $\mathrm{Gu}$ et al. (2015), there was a noticeable prevalence of mental distress among university students during the outbreak of influenza virus subtype H1N1 (H1N1) in Guangzhou. Besides, the severe acute respiratory syndrome (SARS) pandemic in Taiwan also had impacted the mental health status of the general public (Peng et al., 2010). Whereas a study conducted in Saudi Arabia during the Middle East Respiratory Syndrome Corona Virus (MERS-CoV) outbreak shown a significantly higher psychological stress level among students at a university teaching hospital (Al-Rabiaah et al., 2020).

Hence, this study aimed to identify the level of stress perceived by UiTM students during ODL and explore the influence of socio-demographic characteristics on the level of perceived stress among UiTM students during ODL.

\section{Methodology Data Collection}

A cross-sectional survey design was used to investigate the level of stress perceived during ODL by using the tool of a questionnaire which was circulated using Google Form. This survey was conducted from $1^{\text {st }}$ until $25^{\text {th }}$ of June 2021 . The main platform used in this survey was WhatsApp as it is the most popular communication and social platform in Malaysia (MCMC, 2018). A total of 603 students from UiTM Perak Branch, Tapah Campus were taking part in the survey by using a non-probability convenience sampling. All students in this university volunteered to participate in the survey. All questions were required to be answered before submission. To ensure the quality of the questionnaire, the pilot study was run before the actual fieldwork. 


\section{Instruments}

The questionnaire was constructed of three main parts: 1) Demographic characteristics (12 questions); 2) Perceived Stress Scale-10 (PSS-10) (10 questions) of Sheldon Cohen (Cohen, Kamarck, \& Mermelstein, 1983) and 3) Qualitative exploratory question (1 question). In the demographic part, it consists of 11 items which are gender, age group, semester, location of ODL engagement, internet connection quality, number of online courses for the current semester, number of device use in ODL, most popular of Learning Management System (LMS), chat application and live meeting technologies used in ODL and mode of learning preference for future.

The second part of the questionnaire consists of the modified version of the PSS-10 related to ODL. These questions were used to measure the perception of stress in online learning experienced by the students over the past month. The scales used were selected following the population-based stress model with the structure of the stress model (Kocalevent et al., 2013). All items in this part were measured using a 5 -point Likert Scale of the responses $(0=$ Never, 1= Occasionally, 2=Sometimes, 3= Often, 4= Always). Items 1, 2, 3, 6, 9, and 10 were scored directly from 0 to 4 whereas items $4,5,7$, and 8 were scored from 4 to 0 . The overall scale score of $0-13$ was dichotomized to be low stress, $14-26$ indicate moderate stress, and $27-40$ indicate high stress.

The PSS was originally developed by Cohen, Kamarck, and Mermelstein (1983). There are two versions available which are 14 -item and 10 -item instruments. However, this study will use the 10-item version as it is the most widely used version to examine the perceived stress among students (Kaya et al., 2019; AlAteeq et al., 2020; Kostić et al., 2021; Okoro et al., 2021; Jagoda \& Rathnayake, 2021). The acceptable psychometric properties possessed by the PSS also made it easily used (Cohen \& Williamson, 1988; Lee, 2012; Taylor, 2015). A qualitative exploratory question was added to observe the emotions and concerns of the students during ODL.

\section{Statistical Analysis}

The Statistical Package for the Social Sciences (SPSS) version 16.0 software was used to perform statistical analysis on the collected data (SPSS Inc., Chicago, IL, USA). All categorical attributes were expressed as frequencies and percentages. Otherwise, mean \pm standard deviation was used to calculate for continuous attributes. To measure the reliability, Cronbach's alpha correlation coefficient was used. Kline (2000) determines consistency as a reliability coefficient of more than 0.7 . The Cronbach's alpha of the scale in this study was 0.854 (Table 1).

Table 1: Reliability Statistics

\begin{tabular}{|c|c|c|}
\hline $\begin{array}{c}\text { Cronbach's } \\
\text { Alpha }\end{array}$ & $\begin{array}{c}\text { Cronbach's } \\
\text { Alpha Based } \\
\text { on } \\
\text { Standardized } \\
\text { Items }\end{array}$ & N of Items \\
\hline .854 & .846 & 10 \\
\hline
\end{tabular}




\section{Results}

\section{Socio-demographic characteristics}

A total of 603 students have participated and contributed feedback on the implementation of ODL. The tool used in collecting the data has resulted in a satisfying response rate since it is convenient to use and students are already familiar with using Google Form. The qualitative data on the students' perspectives signified their general feedbacks, what they have enjoyed most about ODL, and their recommendations on ODL implementation. The analyzed data were reported and discussed in this section. The socio-demographic characteristics of the students are presented in Table 2.

Table 2: Socio-demographic Characteristics of Participants

\begin{tabular}{|c|c|c|}
\hline Parameter & $n=603$ & $\begin{array}{l}\text { Percentage } \\
(\%)\end{array}$ \\
\hline \multicolumn{3}{|l|}{ Gender } \\
\hline Male & 138 & 22.9 \\
\hline Female & 465 & 77.1 \\
\hline \multicolumn{3}{|l|}{ Age Group } \\
\hline $18-20$ years old & 551 & 91.4 \\
\hline$>21$ years old & 52 & 8.7 \\
\hline \multicolumn{3}{|l|}{ Semester } \\
\hline 1 & 9 & 1.5 \\
\hline 2 & 284 & 47.1 \\
\hline 3 & 9 & 1.5 \\
\hline 4 & 276 & 45.8 \\
\hline 5 & 16 & 2.7 \\
\hline$\geq 6$ & 9 & 1.5 \\
\hline \multicolumn{3}{|l|}{ Location during ODL engagement } \\
\hline Home/City & 391 & 64.8 \\
\hline Home/Rural areas & 159 & 26.4 \\
\hline University Hostel & 53 & 8.8 \\
\hline \multicolumn{3}{|l|}{ Internet connection quality } \\
\hline Poor & 14 & 2.3 \\
\hline Average & 288 & 47.8 \\
\hline Good & 301 & 50.0 \\
\hline \multicolumn{3}{|l|}{$\begin{array}{l}\text { Number of online courses for } \\
\text { current semester }\end{array}$} \\
\hline$<6$ & 474 & 78.6 \\
\hline$\geq 6$ & 129 & 21.4 \\
\hline \multicolumn{3}{|l|}{ Number of device use in ODL } \\
\hline 1 & 63 & 10.4 \\
\hline $2-3$ & 531 & 88.0 \\
\hline$\geq 4$ & 9 & 1.6 \\
\hline \multicolumn{3}{|l|}{ Most popular LMS used in ODL } \\
\hline Google Classroom & 457 & 75.8 \\
\hline Quizizz & 2 & 0.3 \\
\hline uFuture & 144 & 23.9 \\
\hline
\end{tabular}


INTERNATIONAL JOURNAL OF ACADEMIC RESEARCH IN BUSINESS AND SOCIAL SCIENCES Vol. 11, No. 8, 2021, E-ISSN: 2222-6990 @ 2021 HRMARS

\begin{tabular}{|c|c|c|}
\hline $\begin{array}{l}\text { Most popular chat application used } \\
\text { in ODL }\end{array}$ & 12 & \\
\hline Email & 151 & 2.0 \\
\hline Telegram & 440 & 73.0 \\
\hline $\begin{array}{c}\text { MhatsApp popular live meeting } \\
\text { technologies used in ODL }\end{array}$ & & \\
\hline Cisco Webex & 2 & 0.3 \\
\hline Google meet & 600 & 99.5 \\
\hline Microsoft Teams & 1 & 0.2 \\
\hline $\begin{array}{l}\text { Mode learning preference for } \\
\text { future }\end{array}$ & & \\
\hline Blended Learning & 193 & 32.0 \\
\hline Face to face Learning & 338 & 56.1 \\
\hline ODL & 72 & 11.9 \\
\hline
\end{tabular}

The respondents of the study comprise $22.9 \%$ males and $77.1 \%$ females, with a $91.4 \%$ age between 18 to 20 years old. Regarding the semester, students who are currently in the second semester recorded the highest percentage with $47.1 \%$ while the lowest with $1.5 \%$ from those who are currently in their 6th semester and above. In terms of the location of the students during ODL, $64.8 \%$ of them were staying at home located in city areas, followed by $26.4 \%$ staying in the rural areas, and lastly, $8.8 \%$ experienced ODL at university hostel. The students were also asked to rate their internet connection quality during ODL. 50\% of the students had a good quality of internet connection and the least, $2.3 \%$ indicated poor internet connection quality. Whereas the majority of the participants (78.6\%) were taking six or fewer online courses for the semester.

This study also reported that most of the students used more than two devices (88.0\%) or even four devices (1.6\%) during ODL. The result of the survey also revealed that the most popular LMS used by the educators was Google Classroom (75.8\% of the respondents), followed by their Campus' Learning Management System (uFuture/iLearn), and Quizziz. Additionally, the result of the survey indicated that the most preferred social media or chat applications used by both the educators and students were WhatsApp (73.0\%) followed by Telegram (25.0\%), and Email (2\%). Over $99.5 \%$ of the respondents answered that the most preferred live meeting technology was Google Meet. As for preferred learning methods for the future, the majority of the students $(56.1 \%)$ preferred face-to-face learning $(46 \%)$ rather than ODL (11.9\%) and Blended Learning (32.0\%).

\section{Perceived Stress Level}

Table 3 exhibits the responses to the PSS-10 items as answered by the participants. Throughout the survey period, the following trends were reported: $45.6 \%$ of the students were (fairly or very) often upset because of something that happened unexpectedly during $\mathrm{ODL} ; 48.3 \%$ often felt that they were unable to control the important things in their life; $64.2 \%$ of the students often felt nervous and stressed; $44.6 \%$ often found that they could not cope with all the things that they had to do; $50.1 \%$ were often angered due to things that happened are out of their control; $53.9 \%$ often felt that difficulties were increasing during ODL that they could not overcome them. On the contrary, $20.7 \%$ of the students often felt confident in their 
ability to handle personal problems even when they have to cope with ODL, $16.4 \%$ often felt that things were going their way, $19.9 \%$ often felt they were able to control difficulties in their lives, and $30.6 \%$ often felt that everything is under control during ODL.

The overall mean PSS score was $23.72 \pm 6.06$. In general, it was found that the level of PSS among respondents was moderate with $67.5 \%$ of the students had moderate stress and $28.2 \%$ had high stress (Table 4).

Table 3: Responses to the Perceived Stress Scale

\begin{tabular}{|c|c|c|c|c|c|c|}
\hline \multicolumn{2}{|r|}{ Perceived stress scale } & Never & $\begin{array}{c}\text { Almost } \\
\text { never }\end{array}$ & Sometimes & $\begin{array}{l}\text { Fairly } \\
\text { often }\end{array}$ & $\begin{array}{l}\text { Very } \\
\text { often }\end{array}$ \\
\hline 1 & $\begin{array}{l}\text { How often have you been upset } \\
\text { because of something that happened } \\
\text { unexpectedly during ODL? }\end{array}$ & $\begin{array}{c}15 \\
(2.5)\end{array}$ & $\begin{array}{c}76 \\
(12.6)\end{array}$ & $237(39.3)$ & $\begin{array}{c}188 \\
(31.2)\end{array}$ & $\begin{array}{c}87 \\
(14.4)\end{array}$ \\
\hline 2 & $\begin{array}{l}\text { How often have you felt that you } \\
\text { were unable to control the important } \\
\text { things in your life because of ODL? }\end{array}$ & $\begin{array}{c}16 \\
(2.7)\end{array}$ & $\begin{array}{c}85 \\
(14.1)\end{array}$ & $211(35.0)$ & $\begin{array}{c}180 \\
(29.9)\end{array}$ & $\begin{array}{c}111 \\
(18.4)\end{array}$ \\
\hline 3 & $\begin{array}{l}\text { How often have you felt nervous and } \\
\text { stressed about ODL? }\end{array}$ & $9(1.5)$ & $46(7.6)$ & $161(26.7)$ & $\begin{array}{c}205 \\
(34.0)\end{array}$ & $\begin{array}{c}182 \\
(30.2)\end{array}$ \\
\hline 4 & $\begin{array}{l}\text { How often have you felt confident } \\
\text { about your ability to handle your } \\
\text { personal problems during ODL? }\end{array}$ & $\begin{array}{c}28 \\
(4.6)\end{array}$ & $\begin{array}{c}176 \\
(29.2)\end{array}$ & $274(45.4)$ & $\begin{array}{c}102 \\
(16.9)\end{array}$ & $\begin{array}{c}23 \\
(3.8)\end{array}$ \\
\hline 5 & $\begin{array}{l}\text { How often have you felt that things } \\
\text { were going well with ODL? }\end{array}$ & $\begin{array}{c}49 \\
(8.1)\end{array}$ & $\begin{array}{c}188 \\
(31.2)\end{array}$ & $267(44.3)$ & $\begin{array}{c}78 \\
(12.9)\end{array}$ & $\begin{array}{c}21 \\
(3.5)\end{array}$ \\
\hline 6 & $\begin{array}{l}\text { How often have you found that you } \\
\text { could not cope with all the things that } \\
\text { you had to do during ODL? }\end{array}$ & $\begin{array}{c}19 \\
(3.2)\end{array}$ & $\begin{array}{c}84 \\
(13.9)\end{array}$ & $231(38.3)$ & $\begin{array}{c}178 \\
(29.5)\end{array}$ & $\begin{array}{c}91 \\
(15.1)\end{array}$ \\
\hline 7 & $\begin{array}{l}\text { How often have you been able to } \\
\text { control the difficulties that could } \\
\text { appear in yourlife during ODL? }\end{array}$ & $\begin{array}{c}37 \\
(6.1)\end{array}$ & $\begin{array}{c}148 \\
(24.5)\end{array}$ & $298(49.4)$ & $\begin{array}{c}97 \\
(16.1)\end{array}$ & $\begin{array}{c}23 \\
(3.8)\end{array}$ \\
\hline 8 & $\begin{array}{l}\text { How often have you felt that you have } \\
\text { everything under control during ODL? }\end{array}$ & $\begin{array}{c}23 \\
(3.8)\end{array}$ & $\begin{array}{c}97 \\
(16.1)\end{array}$ & $298(49.4)$ & $\begin{array}{c}148 \\
(24.5)\end{array}$ & $\begin{array}{c}37 \\
(6.1)\end{array}$ \\
\hline 9 & $\begin{array}{l}\text { How often have you been angered } \\
\text { that things happened are out of your } \\
\text { control? }\end{array}$ & $\begin{array}{c}14 \\
(2.3)\end{array}$ & $\begin{array}{c}94 \\
(15.6)\end{array}$ & $193(32.0)$ & $\begin{array}{c}207 \\
(34.3)\end{array}$ & $\begin{array}{c}95 \\
(15.8)\end{array}$ \\
\hline 10 & $\begin{array}{l}\text { How often have you felt the } \\
\text { difficulties were increasing during } \\
\text { ODL that you could not overcome } \\
\text { them? }\end{array}$ & $\begin{array}{c}20 \\
(3.3)\end{array}$ & $\begin{array}{c}62 \\
(10.3)\end{array}$ & $196(32.5)$ & $\begin{array}{c}200 \\
(33.2)\end{array}$ & $\begin{array}{c}125 \\
(20.7)\end{array}$ \\
\hline
\end{tabular}


Table 4: Total Scores of the Perceived Stress Scale

\begin{tabular}{|c|c|}
\hline Perceived stress scale & Frequency (\%) \\
\hline Low stress $(0-13)$ & $26(4.3)$ \\
\hline Moderate stress $(14-26)$ & $407(67.5)$ \\
\hline High stress $(27-40)$ & $170(28.2)$ \\
\hline
\end{tabular}

\section{Exploring Students' Emotions and Concerns}

This section deliberates on the themes that emerged from the responses of the students reported from the questionnaire. A total of 603 responses were collected, analyzed, and categorized into a group of themes. Table 5 summarized the themes from the responses.

Table 5: Summary of Themes Based on Items and Program Levels

\begin{tabular}{|c|c|c|c|}
\hline Items & Themes merged & $\begin{array}{c}\text { Total } \\
\text { responses }\end{array}$ & Percentage \\
\hline \multirow[t]{3}{*}{ Positive emotion } & Self-extreme / motivated & 33 & 5.5 \\
\hline & Enjoying ODL & 26 & 4.3 \\
\hline & Okay with ODL & 20 & 3.3 \\
\hline \multirow[t]{17}{*}{ Negative emotion } & Lecturer's delivery style & 2 & 0.3 \\
\hline & Internet connection problem & 14 & 2.3 \\
\hline & Not enjoying ODL & 22 & 3.6 \\
\hline & Inability in time management & 11 & 1.8 \\
\hline & Loneliness & 5 & 0.8 \\
\hline & Deadline online assessment & 9 & 1.5 \\
\hline & $\begin{array}{l}\text { Worry about academic } \\
\text { performance }\end{array}$ & 19 & 3.2 \\
\hline & $\begin{array}{l}\text { Health problems (Anxiety, } \\
\text { Depression, Stress) }\end{array}$ & 112 & 18.6 \\
\hline & $\begin{array}{l}\text { Difficulty in understanding the } \\
\text { course }\end{array}$ & 22 & 3.6 \\
\hline & Exhausted & 91 & 15.1 \\
\hline & Family problem & 4 & 0.7 \\
\hline & Academic workload & 12 & 2.0 \\
\hline & $\begin{array}{l}\text { Inability to concentrate during } \\
\text { lecture }\end{array}$ & 6 & 1.0 \\
\hline & Family distracted & 15 & 2.5 \\
\hline & Loss hope & 30 & 5.0 \\
\hline & Social interaction & 6 & 1.0 \\
\hline & Unmotivated & 53 & 8.8 \\
\hline \multirow[t]{4}{*}{$\begin{array}{l}\text { The recommendations on } \\
\text { ODL implementation }\end{array}$} & Preference on physical class & 1 & 0.2 \\
\hline & Preference on ODL class & 1 & 0.2 \\
\hline & $\begin{array}{l}\text { Preference on Blended } \\
\text { Learning }\end{array}$ & 1 & 0.2 \\
\hline & $\begin{array}{l}\text { Use pre-recorded lesson more } \\
\text { /note }\end{array}$ & 1 & 0.2 \\
\hline Other feedback & Mixed feeling & 66 & 10.9 \\
\hline
\end{tabular}




\begin{tabular}{|l|l|c|c|}
\hline & No comment & 21 & 3.5 \\
\hline Total responses & & 603 & $\mathbf{1 0 0 . 0}$ \\
\hline
\end{tabular}

Based on Table 5, a total of 26 themes have emerged from the responses that are collected from the open-ended question. The qualitative exploratory question about the emotions and concerns of the participants has shown diverse results. There were positive and negative emotions related to ODL obtained from different broad themes that emerged from data analysis. Most of these themes were directly connected to the experience of online distance learning. The first theme is on the positive emotion on ODL implementation which reported 79 responses with three themes namely self-extreme/motivated, enjoying ODL, and okay with ODL. These three themes resulted from the advantages of distance learning, such as the flexibility and convenience offered by ODL and being with family. Another interesting factor that arises from the responses is they claimed that ODL helped them to cope with the lesson better since most lectures are delivered through video recording. They feel that it is convenient because they can replay the video numerous times to improve their understanding of the subject. The self-extreme/motivated theme has gathered the most frequent feedback by the students in which most responses came from part four students $(45.8 \%)$. The possible reason could be that most of the students that participated in this study are more matured, hence better at expressing their thoughts on ODL implementation. Furthermore, some responses that they are happy to attend online classes from home as they do not have to get out of bed and avoid the morning rush to attend classes. The second source of motivation is family. Surprisingly, not only that, they enjoyed ODL due to being able to be with their families during COVID-19. They treat this situation as an advantage since they can study without thinking about food supplies or safety problems which encouraged them to focus on their studies. Besides that, other sources of motivation are the availability of university support and motivational programs. The results from this study were consistent with previous studies (Muda \& Bit-Lian, 2019; Mathew \& Chung, 2020).

However, when it comes to negative emotions, their claims include depressed, overwhelmed, anxious, stressed, sad, tired, disappointed, worried, bored, unmotivated, and nervous. These results were in line with a study, Emotional Presence, Learning, and the Online Learning Environment done by Cleveland-Innes and Campbell (2012) which agrees with a previous work reported by several past research (Moeller et al., 2020; Camacho-Zuñiga et al., 2021) in the frame of a global pandemic. Among these sixteen negative emotion themes, the most frequent feedback given was related to health problems (anxiety, depression, and stress) and exhaustion. Some students clarified their reasons as it was difficult to cope with ODL due to poor internet connection. Besides that, some students were reported to worry about their grades and their future. Exhaustion has been reported as the most frequently experienced feeling by university students (Muda \& Bit-Lian, 2019). It was also identified to have detrimental impacts on students' abilities to concentrate, learn, and regulate their feelings (Owens \& Group, 2014). We assume the reports of feeling tired the time of the COVID-19 pandemic also attribute to the uncertainty of the confinement and an unclear end to the current crisis. Furthermore, one student admitted that she needs to seek psychiatric help and was diagnosed with anxiety. She was prescribed an antidepressant medication to assist her coping and controlling things. Meanwhile, some of the students declared that staying at home with their families caused difficulties and challenges to focus on their online studies. This unfavorable learning environment, together with conflicts between family/work and 
study schedule and lack of support from family, employer, friends, etc was in line with Camacho-Zuñiga et al (2021). Besides that, difficulties related to studying especially for calculation subjects and time management were also reported from this study.

In the 'others feedback' category theme, the majority of them have mixed feelings of both happiness and struggle in making the best effort going through ODL during this hard time and hoping for a better future. Some concerns that stress during ODL might be due to the inability for proper time management. However, they also recommended that the government provides special internet data aid for students as ODL consumed a lot of their mobile data. Some hoped that internet service provider companies in Malaysia can improve their services in providing better internet connections to curb the internet connection problems in their areas as a means to ease their participation during ODL. Besides that, they strongly recommend using more pre-recorded videos compared to other methods. Furthermore, the students suggested reducing the number of assignments and requested a longer time to complete the assignments. Other than that, quite a significant number indicated that ODL should not be continued in the upcoming semesters due to poor internet connection, budget constraints, and time management issues.

In general, this study found that UiTM students showed moderate stress about the overall implementation of ODL and these findings were consistent with many Malaysian press and news agencies and some members of education institutions began reporting student complaints about the anxieties and challenges they experienced when learning online (Lim, 2020; Menon, 2020). The major obstacle that beset many students during this unfortunate COVID-19 pandemic is the poor internet connection. Even though many students expressed satisfaction with online learning as the main delivery method of ODL, poor internet connection was a major factor that contributed to their lack of intention to continue using it in the future (Mathew \& Chung, 2020). Major sources of stress were related to technical problems of ODL such as limited internet data, unstable connection, unfamiliarity with the study environment, and "new normal" study practices in their home. This is consistent with the past findings from previous research on ODL and e-learning (Al-Kumaim et al., 2021; Chung, Supramaniam \& Dass, 2020; Çakýroglu, 2014; Cole, Shelly \& Swartz, 2014). The results of the study showed that 'academic workload', 'high academic workload', 'deadline of assignment', 'internet connection', 'learning environment', 'family problems' were the major causes of stress among the students which in line with previous studies (Wang et al., 2021; Kwaah \& Essilfie, 2017).

\section{Conclusions}

The connection between students and stress cannot be denied as it has been discussed in many research all over the world. The emergence of the COVID-19 pandemic has led to greater concern in causing an increase in anxiety and stress among students globally. Through this study, it can be concluded that UiTM students showed moderate stress about the implementation of ODL during the pandemic. The contributing factors to this are a poor internet connection, academic workload, high academic workload, deadline of assignment, internet connection, learning environment, and family problems. Although ODL has been successfully implemented for the past one and a half years, several improvement measures are still required. On the bright side, ODL as the new norm of teaching and learning mechanism has proven that learning has no boundaries. Future research should consider 
getting opinions and views from the lecturers' perspectives as the instructors of ODL to match the expectation of students and lecturers on ODL implementation.

\section{Corresponding Author}

Nor Mariyah Abdul Ghafar

Faculty of Computer \& Mathematical Sciences, Universiti Teknologi MARA (UiTM), Perak Branch, Tapah Campus, Malaysia.

Email: norma674@uitm.edu.my

\section{References}

AlAteeq, D. A., Aljhani, S., AlEesa, D. (2020). Perceived stress among students in virtual classrooms during the COVID-19 outbreak in KSA. J Taibah Univ Med Sc, 15(5), 398-403.

Al-Kumaim, N.H., Alhazmi, A.K., Mohammed, F., Gazem, N.A., Shabbir, M.S. \& Fazea, Y. (2021). Exploring the Impact of the COVID-19 Pandemic on University Students' Learning Life: An Integrated Conceptual Motivational Model for Sustainable and Healthy Online Learning. Sustainability, 13(5), 2546, 1-20.

Almaiah, M. A., Al-Khasawneh, A. \& Althunibat, A. (2020). Exploring the critical challenges and factors influencing the E-learning system usage during COVID-19 pandemic. Education and Information Technologies, 25, 5261-5280. https://doi.org/10.1007/s10639-02010219-y

Al-Rabiaah, A., Temsah, M. H., Al-Eyadhy, A. A., Hasan, G. M., Al-Zamil, F., Al-Subaie, S., Alsohime, F., Jamal, A., Alhaboob, A., Al-Saadi, B., Somily, A. M. (2020). Middle East Respiratory Syndrome-Corona Virus (MERS-CoV) associated stress among medical students at a university teaching hospital in Saudi Arabia. Journal of Infection and Public Health, 13(5), 687-691. https://doi.org/10.1016/j.jiph.2020.01.005

Çakýroglu, Ü. (2014). Evaluating students' perspectives about virtual classrooms with regard to Seven Principles of Good Practice. South African Journal of Education, 34(2), 01-19.

Camacho-Zuñigaa, C., Pego, L., Escamilla, J., Hosseini. S. (2021). The impact of the COVID 19 pandemic on students' feelings at high school, undergraduate, and postgraduate levels. Heliyon, 7(3), 1-11.

Cant, M. C., Wiid, J. A., \& Machado, R. (2013). The Characteristics of a Good ODL Practitioner. International Business \& Economics Research Journal (IBER), 12(11), 1317-1330.

Chung, E., Supramaniam, G., \& Dass, L. C. (2020). Online learning edginess among university students in Malaysia amidst Covid-19. Asian Journal of University Education, 16(2), 4658. DOI: https://doi.org/10.24191/ajue.v16i2.10294.

Cleveland-Innes, M. \& Campbell, P. (2012). Emotional presence, learning, and the online learning environment. The International Review of Research in Open and Distributed Learning, 13(4), 269-292.

Cohen, S. \& Williamson, G. (1988). Perceived stress in a probability sample of the United States. In: Spacapan S, Oskamp S, editors. The social psychology of health, 31-67.

Cohen, S., Kamarck, T., \& Mermelstein, R. (1983). A global measure of perceived stress. Journal of health and social behavior, 385-396.

Cole, M. T., Shelley, D. J., \& Swartz, L. B. (2014). Online instruction, e-learning, and student satisfaction: A three-year study. The International Review of Research in Open and Distributed Learning, 15(6), 111-131. https://doi.org/10.19173/irrodl.v15i6.1748 
Ghosh, S., Nath, J., Agarwal, S., Nath, A. (2012). Open and Distance Learning (ODL) Education System: Past, Present and Future - A Systematic Study of an Alternative Education System. Journal of Global Research in Computer Science, 3(4), 53-57.

Gu, J., Zhong, Y., Hao, Y., Zhou, D., Tsui, H., Hao, C., Gao, Q., Ling, W., Lau, J. T. F. (2015). Preventive Behaviors and Mental Distress in Response to H1N1 Among University Students in Guangzhou, China. Asia Pacific Journal of Public Health, 27(2), 1867-1879. https://doi.org/10.1177/1010539512443699

Jagoda, T. \& Rathnayake, S. (2021). Perceived stress and learning environment among nursing students: A cross-sectional collegian. https://doi.org/10.1016/j.colegn.2021.03.003

Kaya, C., Tansey, T. N., Melekoglu, M., Cakiroglu, O., Chan, F. (2019). Psychometric evaluation of Turkish version of the Perceived Stress Scale with Turkish college students. J Ment Health, 28(2), 161-167.

Khouja, J.N., Munafò, M.R., Tilling, K., Wiles, N. J., Joinson, C., Etchells, P. J., John, A., Hayes, F. M., Gage, S. H., Cornish, R. P. (2019). Is screen time associated with anxiety or depression in young people? Results from a UK birth cohort. BMC Public Health, 19, 82. https://doi.org/10.1186/s12889-018-6321-9

Kline, P. (2000). A Psychometrics Primer. London: Free Association Books.

Kocalevent, R. D., Klapp, B. F., Albani, C., \& Brähler, E. (2013). ). Associations of Resources Factors, Chronic Activated Distress, and Fatigue in the German General Population. PPmP-Psychotherapie. Psychosomatik. Medizinische Psychologie, 63(3-4), 115-121.

Kostić, J., Žikić, O., Đorđević, V., Krivokapić, Ž. (2021). Perceived stress among university students in south-east Serbia during the COVID-19 outbreak. Annals of General Psychiatry, 20(1), 1-8. https://doi.org/10.1186/s12991-021-00346-2

Kwaah, C.Y. \& Essilfie, G. (2017). Stress and coping strategies among distance education students at the University of Cape Coast, Ghana. Turkish online journal of distance education, 18 (3), 120-134.

Lee, E. H. (2012). Review of the psychometric evidence of the perceived stress scale. Asian nursing research, 6(4), 121-127.

Lim, I. (2020, 30 May). Reality for Malaysia's University Students: Online Learning Challenges, Stress, Workload; Possible Solutions for Fully Digital Future until Dec. Malay Mail. https://www.malaymail.com/news/malaysia/2020/05/30/reality-for-malaysiasuniversity-students-online-learning-challenges-stress/1870717

Malaysian Communications and Multimedia Commission (MCMC). (2018). Internet users survey 2018: statistical brief number twenty-three. Cyberjaya.

Mathew, V. N., \& Chung, E. (2020). University Students' Perspectives on Open and Distance Learning (ODL) Implementation Amidst COVID-19. Asian Journal of University Education (AJUE), 16(4), 152-160.

Menon, S. (2020, 15 April). Students Anxious but Ready to See it Through. The Star. https://www.thestar.com.my/news/nation/2020/04/15/students-anxious-but-readyto-see-it-through.

Mheidly, N., Fares, M. Y., \& Fares, J. (2020). Coping With Stress and Burnout Associated with Telecommunication and Online Learning. Front. Public Health, 8:574969. doi: 10.3389/fpubh.2020.574969 
Moeller, J., Brackett, M. A., Ivcevic, Z., White, A. E. (2020). High school students' feelings: discoveries from a large national survey and an experience sampling study. Learn. InStruct. 66, 101301. https://doi.org/10.1016/j.learninstruc.2019.101301.

Muda, S., \& Bit-Lian, Y. (2019). Perceived challenges in open and distance learning among nursing students of Open University Malaysia: A descriptive analysis. International Conference on Education (ICE 2019), 429-440.

Okoro, R. N., Biambo, A. A., \& Jamiu, M. O. (2021). Perceived stress and its predictors, stressors and coping strategies among undergraduate pharmacy students in northern Nigeria. Currents in Pharmacy Teaching and Learning, 13(7), 804-811. https://doi.org/10.1016/j.cptl.2021.03.014

Owens, J., \& Group, A.S.W. (2014). Insufficient sleep in adolescents and young adults: an update on causes and consequences. Pediatrics, 134(3), e921-e932.

Peng, E. Y., Lee, M. B., Tsai, S. T., Yang, C. C., Morisky, D. E., Tsai, L. T., Weng, Y. L., Lyu, S. Y. (2010). Population-based Post-crisis Psychological Distress: An Example from the SARS Outbreak in Taiwan. Journal of the Formosan Medical Association, 109(7), 524-532. https://doi.org/10.1016/S0929-6646(10)60087-3.

Sansone, R. A. \& Sansone, L. A. (2013). Cell phones: the psychosocial risks. Innov Clin Neurosci, 10(1):33-7. PMID: 23439568; PMCID: PMC3579483.

Taylor, J. M. (2015). Psychometric analysis of the ten-item perceived stress scale. Psychological assessment, 27(1), 90-101. https://doi.org/10.1037/a0038100.

Višnjić, A., Veličković, V., Sokolović, D., Stanković, M., Mijatović, K., Stojanović, M., Milošević, Z., Radulović, O. (2018). Relationship between the Manner of Mobile Phone Use and Depression, Anxiety, and Stress in University Students. International Journal of Environmental Research and Public Health, 15(4): 697. https://doi.org/10.3390/ijerph15040697.

Wang, J., Liu, W., Zhang, Y., Xie, S., Yang, B. (2021). Perceived Stress among Chinese Medical Students Engaging in Online Learning in Light of COVID-19. Psychology Research and Behavior Management, 14, 549-562. 